\title{
Communication Strategies in English as a Second Language (ESL) Context
}

\author{
Lidya Ayuni Putri \\ The University of Indonesia \\ E-mail: putri.basmalah@yahoo.com
}

Doi:10.7575/aiac.alls.v.4n.1p.129

Received: $02 / 12 / 2012$

URL: http://dx.doi.org/10.7575/aiac.alls.v.4n.1p.129

Accepted: 04/01/2013

\begin{abstract}
Communication is important for people around the world. People try to communicate to other people around the globe using language. In understanding the differences of some languages around the world, people need to learn the language of other people they try to communicate with, for example Indonesian people learn to acquire English. In the context that English in Indonesia is considered as a foreign language, it causes the learners of English in Indonesia understand not only the language but also the culture. Foreign language learners may encounter various communication problems when their interlanguage is limited. In order to convey their messages and remain in a conversation until their communication goal is achieved, ESL (English as a Second Language) learners need to employ communication strategies, which have been defined generally as devices used by second language learners to overcome perceived barriers to achieving specific communication goals (Færch \& Kasper, 1983). In order to avoid certain miscommunication, the teacher of English in Indonesia should also give their learners the understanding of communication strategies.
\end{abstract}

Keywords: Communication Strategies, ESL, Context

\section{Introduction}

In real life, people use language to communicate to other people. People often use the same language with people they talk to in order to make them understand and get the meaning of the message. This event can be called as communication. Communication problems occur when the encoded message differs from the decoded message. In other words, the message sent is not the message received. In daily communicative interaction, communication strategies are often used as communication is basically functional. Communication is not just what a message is about but what it wants to achieve.

Foreign language learners may encounter various communication problems when their interlanguage is limited. In order to convey their messages and remain in a conversation until their communication goal is achieved, ESL (English as a Second Language) learners need to employ communication strategies, which have been defined generally as devices used by second language learners to overcome perceived barriers to achieving specific communication goals (Færch \& Kasper, 1983).

Language learning cannot be separated from its culture. Language is a clear manifestation of culture. A word can has both cognitive meaning and cultural meaning. Cultural meaning refers to words and expressions which represent cultural perception, values and behavior. At discourse level, the link between language, communication and culture is virtually inseparable.

Miscommunication occurs when one interprets communicative rules of one culture in terms of the rules of another culture. In the process of learning a second language, learners make some errors due to first language interference. By knowing strategies to avoid misinterpretation between different backgrounds of speakers, the problems mentioned before shall be avoided easily.

Language teaching at school has traditionally been aimed at developing linguistic competence. Teachers tend to teach grammar and linguistic features without letting their learners practice and improve their communication in English. Probably this is one reason that cause some learners are good in English but they cannot use English orally. This problem may be solved by the teacher to introduce communication strategies to their learners in order to avoid them from some communication problems and equip them with strategies to overcome the problems of speaking that they are dealing with.

\section{Discussion}

\subsection{Definitions of Communication Strategies}

Some scholars define communication strategies differently. They point out the definition by stating different angle of perception about the communication strategies itself. Corder (1983) defines such strategies as "a systematic technique 
employed by a speaker to express his meaning when faced with some difficulty". The term communication strategies is often limited to strategies resorted to when the second language learner has difficulty with communicating. Thus, communication strategy is used when things go wrong, it is "a spare tyre for emergencies" (Cook, 1993, p. 119).

Ellis (1985) defines communication strategies as psycholinguistic plans which exist as part of the language user's communicative competence. They are potentially conscious and serve as substitutes for production plans which the learner is unable to implement" (p. 182). Ellis (1994) also suggests that communication strategies be seen as a set of skills, which learners use in order to overcome their inadequacies in the target language. When students fail to communicate because of their limited knowledge in the target language they have to find a way to communicate in other ways, for example by imitating sounds, code-switching or avoiding the topic.

Communication strategies are usually associated with spoken language and research has shown that students tend to use various communication strategies when they are unable to express what they want to say because of their lack of resources in their second language (L2) (Hedge 2000:52). When learners experience that fluency in their first language (hereafter L1) does not follow the same pattern as their L2, a gap is created in the knowledge of their L2. These gaps can take many forms: a word, a phrase, a structure, a tense marker or an idiom (Bialystok 1990:1). In order to overcome that gap, learners have two options: they can either leave the original communicative goal or they can try to reach other alternative plans and use other linguistic means that they have at their disposal.

In line with the explanation above, the writer may say that communication strategies are the strategies of communication that someone of non-native speaker of one language should know in order to avoid some problems that may occur during the conversation with the interlocutors. It is also important to know that culture and language cannot be separated, therefore in the context of language teaching, the knowledge of language and its culture need to be taught as well to second language learners. By letting the learners know about it, they may solve their problems during communication and may choose properly which strategies of communication they are going to use. The role of teachers in introducing communication strategies to the learners could determine their learners' successfulness in facing problems of communication occur in real life situations.

\subsection{Taxonomy of Communication Strategies}

Some scholars define types of communication strategies based on their researches and findings. Therefore, the taxonomy and the type of communication strategies may differ from one scholar to other scholars. The taxonomy in the table below is proposed by Bialystok (1990) and adapted from Varadi (1973), Tarone (1977), and Faerch and Kasper (1983).

\begin{tabular}{|c|c|c|}
\hline Communication Strategies & Strategies & Explanation of Strategy \\
\hline \multirow{2}{*}{$\begin{array}{l}\text { A. Avoidance or Reduction } \\
\text { Strategies }\end{array}$} & a. Message abandonment & $\begin{array}{l}\text { leaving a message unfinished } \\
\text { because of linguistic } \\
\text { difficulties }\end{array}$ \\
\hline & b. Topic avoidance & $\begin{array}{l}\text { avoiding topic areas or } \\
\text { concepts which pose } \\
\text { linguistic difficulties }\end{array}$ \\
\hline \multirow{4}{*}{$\begin{array}{ll}\text { B. Achievement } & \text { or } \\
\text { Compensatory Strategies } & \end{array}$} & a. Circumlocution & $\begin{array}{l}\text { Describing or exemplifying } \\
\text { the target object or action } \\
\text { (e.g., the thing you open } \\
\text { doors with for describing } \\
\text { keys) }\end{array}$ \\
\hline & b. Approximation & $\begin{array}{l}\text { Using an alternative terms } \\
\text { which expresses the meaning } \\
\text { of target lexical items as } \\
\text { closely as possible (e.g., ship } \\
\text { for describing sail boat) }\end{array}$ \\
\hline & c. Use of all-purpose words & $\begin{array}{l}\text { Extending a general empty } \\
\text { lexical item to contexts } \\
\text { where specific words are } \\
\text { lacking (e.g., overuse of } \\
\text { thing) }\end{array}$ \\
\hline & d. word-coinage & $\begin{array}{l}\text { Creating non-existing L2 } \\
\text { word based on a supposed } \\
\text { rule (e.g., paintist for painter) }\end{array}$ \\
\hline
\end{tabular}




\begin{tabular}{|l|l|l|}
\hline & e. Use of non-linguistic means & $\begin{array}{l}\text { Mime, gestures, facial } \\
\text { expressions }\end{array}$ \\
\cline { 2 - 3 } & f. Literal translation & $\begin{array}{l}\text { Translating literally a lexical } \\
\text { item an idiom, a compound } \\
\text { word or structure from L1 to } \\
\text { L2 }\end{array}$ \\
\cline { 2 - 3 } & g. Foreignizing & $\begin{array}{l}\text { Using a L1 word by } \\
\text { adjusting it to L2 } \\
\text { phonologically (e.g., adding } \\
\text { a L2 suffix) }\end{array}$ \\
\cline { 2 - 3 } & h. Code switching & $\begin{array}{l}\text { Using a L1 word with L1 } \\
\text { pronunciation }\end{array}$ \\
\cline { 2 - 3 } & i. Appeal for help & $\begin{array}{l}\text { Turning to the conversation } \\
\text { partner for help directly or } \\
\text { indirectly }\end{array}$ \\
\hline $\begin{array}{l}\text { C. Stalling or time gaining } \\
\text { strategies }\end{array}$ & a. Use of fillers/hesitation \\
devices & $\begin{array}{l}\text { Using filling words or } \\
\text { gambits to fill in pauses and } \\
\text { to gain time to think (e.g., } \\
\text { now, let me see...) }\end{array}$ \\
\hline
\end{tabular}

Johnstone $(1989,71$, cited in Mali, 2007, 48) lists achievement production strategies as follows: Code-switching and gesticulation, Literal translation and foreignizing, Word coinage, Simplification, Generalization, Paraphrase, Restarts and approximation, Establish foreign identity, and Appeal for repair and confirmation.

It can be seen that some types of communication strategies offered by different scholars are almost similar one another but may have different meaning on its applications. In addition, the uses of those strategies above are also varied from one another. The writer claims that only some strategies are used frequently by some people to overcome the problem they are dealing with during the process of communication. People often use gestures or miming, code switching, and fillers/hesitation to fill the gap that occur when they try to convey the meaning they intended. It is better for the teacher to raise their learners' awareness about different kinds of taxonomy of communication strategies from different scholars and let them practice so that they have enough knowledge to overcome problems of communication in real life situations.

\subsection{Factors Affecting the Choice of Communication Strategies}

\section{a. Learners'Attitude}

The learners' attitude towards a particular strategy affects the use of that strategy. Generally, a positive attitude towards the strategy leads to a high frequency of using it. Learners' positive attitude towards stalling strategy and non-linguistic means strategy, for example, leads to a learner's active use of these strategies. Similarly, a negative attitude to reduction strategies does not result in low frequency of using of them. This "abnormality" may result from the learning situation, traditional teaching methods, and the inadequacy of strategic competence.

\section{b. Learners'Level of L2 Proficiency}

The proficiency level of an individual may influence his/her choice of communication strategies. Generally in speaking, learners of high proficiency level tend to use achievement or L2-based strategies such as paraphrase, whereas the learners of limited proficiency prefer reduction or L1-based strategies.

\section{c. Learners'Personality}

The learner's personality may also affect the choice of communication strategies. Based on the approach of storytelling, Tarone (1977) suggests that personality has a very close relation with the choice of communication strategies.

\section{d. Learning Situation}

Of the factors affecting the use of strategies, learning situation, in which the learner has learned his/her interlanguage, seems to be particularly powerful. For instance, learners may use less-strategies in a formal classroom context than in daily actual communication, especially when the teaching focus is on accuracy of L2 use rather than on fluent communication. The learning situation may also affect the type of strategy used.

\section{e. Communication Context}

Communication context also influences a learner's preference for particular communication strategies. The learner's communicative experience and his/her assessment of the context will determine his/her choice of communication strategies.

\subsection{Teachability and teaching of Communication Strategies}

The teachability of communication strategies has been controversial. There are different arguments for or against communication strategies instruction. One of possible reasons for the controversy is that most of the arguments on both 
sides are based on indirect evidence. Hence, there is great need to conduct empirical studies to examine the effect of communication strategies teaching.

Maleki's (2007) study on the teachability of communication strategies found that communication strategies teaching were pedagogically effective, that interactional strategies were employed in a more effective and extensive way, that communication strategies were helpful to language learning, and that language teaching materials containing communication strategies were more effective than those without them.

Tian and Zhang (2005) investigated the effectiveness of the training of communication strategies on non-English majors. Some of their findings of the study showed that the students in the experimental class used more communication strategies in group discussion after training, that with the help of the communication strategies in group discussion, the students' communicative competence improved greatly, and that the students held a positive attitude towards communication strategies.

Despite the fact that many SLA researchers lend support to communication strategies training; some opposition to it has been expressed. Bialystok (1990) and Kellerman (1991) argue that one should teach the language itself rather than the strategies. Schmidt (1983) believes that L2 learners develop their strategic competence at the expense of their linguistic competence. According to Skehan (1998), using communication strategies by skilled learners may hinder the development of their interlanguage knowledge resources.

Teaching communication strategies to the students is a good thing to do but as some scholars mentioned their support and against to it, teacher needs to consider that the availability of the strategies itself will not goes further than the availability of using the target language in the classroom.

\section{Conclusion}

Communication strategies have a direct influence on communication and play a constitutive role in second language acquisition. Communication strategies in general keep the channel open and help to secure more input for learners. There are many factors affecting the use of communication strategies, such as: a learner's level of language proficiency, a learner's personality, and his/her attitude towards a particular strategy; and communication situations. These factors interactively affect the use of communication strategies.

Communication strategies help students to get their meanings across and ensure listener comprehension. It is believed that only when ESL learners realize the need to communicate and exchange information that more interactions will be generated. In other hand, although it is good to reinforce the learners to use communication strategies, teachers should also notice that the learners shall not depend much on it to improve their speaking in target language.

\section{References}

Bialystok, E. (1983). Some Factors in the Selection and Impletion of Communication Strategies. In C. Faerch and G. Kasper (eds.) Strategies in Interlanguage Communication. London: Longman.

Bialystok, E. (1990). Communication Strategies. Oxford: Basil Blackwell.

Cohen, A. (1998). Strategies in Learning and Using a Second Language. Harlow, Essex: Longman.

Cook, V. (1993). Linguistics and second language acquisition. London: Palgrave.

Corder, S.P. (1978). Language Learner Language. In J.C. Richards (ed.) Understanding Second and Foreign Language Learning: Issues and Approaches. Rowley, MA: Newbury House.

Corder, S. P. (1983). Strategies of communication. In C. Faerch \& G. Kasper (Eds.), Strategies in interlanguage communication (pp. 15-19). London: Longman.

Dörnyei,Z.(1995). On the teachability of communication strategies. TESOL QUARTERLY, 29, 1, 55-81.

Ellis, R. 1985. Understanding Second Language Acquisition. Oxford: Oxford University Press.

Ellis, R. 1994. The Study of Second Language Acquisition. Oxford: Oxford University Press.

Ellis, R. \& G. Barkhuizen. (2005). Analysing Learner Language. Oxford: Oxford University Press.

Faerch, C., \& Kasper, G. (Eds) (1983). Plans and strategies in foreign language communication. In C. Faerch \& G. Kasper (Eds). Strategies in interlanguage communication (pp. 20-60). London: Longman.

Hedge, T. (2000). Teaching and learning in the language classroom. Oxford: Oxford University Press.

Johnstone, R. (1989). Communicative Interaction. London: CILT.

Kellerman, Eric. 1991. Compensatory strategies in second language research: A critique, a revision, and some (non)implications for the classroom. In R. Phillipson, E Kellerman, L. Selinker, M. Sharwood Smith, and M. Swain (Eds). Foreign/second language pedagogy research; A commemorative volume for Claus Færch: 142-161. Clevedon, England: Multilingual Matters.

Kong, J. J. 2004. 开展交际策略教学的一项研究 [A study of communication strategy training]. Foreign Language World, 5, 33-39.

Maleki, A. 2007. Teachability of communication strategies: An Iranian experience. System, 35, 583-594. 
Mali, Z. O. (2007). Exploring communication strategy use by learners of Isizulu in Synchronous computer-mediated communication (S-CMC). Unpublished Ph. D dissertation, Iowa University, USA.

Oxford, R. L. (2001). Language Learning Strategies. In R. Carter \& D. Nunan (Eds.), Teaching English to Speakers of Other Languages. Cambridge: Cambridge University Press, 166-172.

Schmidt, R. (1983). Interaction, acculturation and the acquisition of communication competence. In N. Wolfson \& E. Judd (Eds.), Sociolinguistics and Second Language Acquisition. Rowley: Newbury House, 137-174.

Skehan, P. (1998). A Cognitive Approach to Language Learning. Oxford: Oxford University Press.

Tarone,E. (1977). Concious communication strategies in interlanguage: a progress report. On TESOL 1977. Washington, D.C: TESOL.

Tarone, E. (1983). Some thoughts on the notion of “communication strategy”. In C. Faerch \& G. Kasper (Eds.), Strategies in interlanguage communication (pp. 61-74). London: Longman.

Tian, J. P. \& Zhang, X. G. 2005. 非英语专业学生在小组讨论中使用交际策略的研. [The study of communication strategies used by non-English majors in group discussion]. Foreign Language World, 3, 61-67.

Váradi,T. (1973). Strategies of target language learner communication: message adjustment. Paper presented at the sixth conference of the Romanian-English Linguistics Project in Timisoara. 